\title{
Association of HLA-DRB1 alleles with giant cell tumour of bone
}

\author{
S S Varanasi, N A Athanasou, I Briceno, S S Papiha, H K Datta
}

\begin{abstract}
Aim-To examine the possible influence of the MHC class II antigens alleles in the formation of the multinucleate aggressive giant cell tumour of bone.

Methods-HLA class II antigen alleles were investigated in eight white patients from north east England with confirmed diagnosis of giant cell tumour of bone. All had locally aggressive, immunophenotypically HLA-DR negative giant cell tumours.

Results-Five of the eight patients were found to be positive for HLADRB $1^{*} 0801 / 3$, the distribution of this allele in healthy white controls being quite low $(2 \%)$. All but one of the patients possessing DRB1*080 also expressed DRB1*070.

Conclusions-HLA-DRB ${ }^{\star}{ }^{*} 080$ is predominant in patients with immunophenotypic HLA-DR negative giant cell tumour of bone; individuals with the genotype $070 /$ 080 are at particularly high risk of developing giant cell tumour of bone.

$(\mathcal{F}$ Clin Pathol 1999;52:782-784)
\end{abstract}

Keywords: HLA-DR genotyping; giant cell tumour of bone; osteoclastogenesis

Giant cell tumour of bone, constituting 5\% of all bone tumours, commonly occurs in the third and fourth decade of life. ${ }^{1}$ It is a potentially aggressive stromal growth capable of causing considerable damage owing to its bone resorbing capacity. Although occasionally known to metastasise, most tend to produce damage at the primary site. The aetiology of these tumours is unknown and there is no evidence of familial occurrence.

In recent years characterisation studies have attempted to classify giant cells into two main subtypes on the basis of their resorptive activity, calcitonin responsiveness, and HLA-DR immunophenotypic status. ${ }^{2}$ It has been suggested that giant cells showing avid bone resorptive activity tend to be HLA-DR negative and are sensitive to inhibition by calcitonin, while cells that are HLA-DR positive lack resorptive activity and are insensitive to calcitonin. ${ }^{2}$ However, exceptions to this association have been reported, with immunophenotypic HLA-DR positivity and responsiveness to calcitonin. ${ }^{3}$ This apparent association between the HLA-DR and giant cell tumour of bone led us to examine the possible influence of the MHC class II antigen alleles in the formation of aggressive multinucleate giant cell tumours.

\section{Methods}

SELECTION OF PATIENTS

We selected eight white British patients from north east England with a confirmed diagnosis of locally destructive giant cell tumour of bone. The samples consisted of biopsies collected for pathological examination from patients undergoing surgery for resection of the tumour. The tumours selected did not express HLA-DR antigen and showed evidence of extensive bone resorption.

\section{HLA-DR GENOTYPING}

Embedded tissue was scraped free from the paraffin blocks and washed in xylol. The remnant bone and soft tissue were suspended in two volumes of ethanol, agitated, and collected by centrifugation. Liquid nitrogen was added to the tissue and the supercooled bone was crushed into smaller pieces. The crushed bone was incubated at $37^{\circ} \mathrm{C}$ for three days in ESP solution $(0.5 \mathrm{mM}$ ethylene diamine tetra-acetic acid ( $\mathrm{pH}$ 9), $0.019 \mathrm{mg} / \mathrm{ml}$ sodium dodecyl sulphate (SDS), $1 \mathrm{mg} / \mathrm{ml}$ proteinase $\mathrm{K})$. Genomic DNA was extracted by

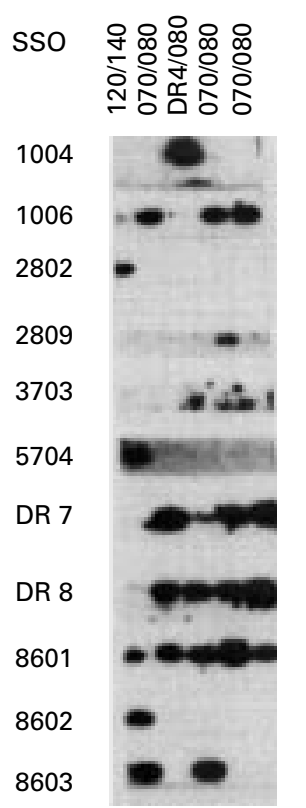

Figure 1 A representative Southern blot of HLA-DRB1 allele genotyping carried out using sequence specific oligonucleotide (SSO) analysis. The details of the PCR conditions employed for the amplification of the genomic $D N A$, including the sequences of the primers used, are given in the text. Following agarose gel electrophoresis, the amplified DNA was transferred to nylon filter by Southern transfer and sequentially probed with oligonucleotide probes (table 1). The genotyping was carried out as recommended by The International Histocompatibility Workshop and Conference. 
Table 1 The sequence of sense and antisense of DRB1 oligonucleotide probes

\begin{tabular}{|c|c|c|c|}
\hline$D R B 1$ & Sequence & $\begin{array}{l}\text { Amino acid } \\
\text { position } 5\end{array}$ & \\
\hline 1. $0102,1201, \mathrm{DRB} 5 \star 0201,0202$ & CTACGGGGCTGTGGAGA & 82 & Sense \\
\hline 2. 0401-09 & АСТTСТАТСАССАAGAG & 30 & Sense \\
\hline 3. $0405,0409,0801(0803,1303)$ & GCGGCCTAGCGCCGAGT & 54 & Sense \\
\hline 4. 1201 & AGGAGGAGCTCCTGCGC & 34 & Sense \\
\hline 5. 0701,0702 & ACGGAGCTAGGGCGGCC & 51 & Sense \\
\hline 6. 0901 & TGCGGTATCTGCACAGA & 24 & Sense \\
\hline 7. $0801,0802,0803$ & GCGGGCCCTGGTGGACA & 71 & Sense \\
\hline 8.1001 & GAGCGGAGGCGTGCCGC & 69 & Sense \\
\hline 9. DRB1 1401 & CTGCGGAGCACTGGAAC & 57 & Sense \\
\hline $10.0101,0102,0103$ & ATAGATGCATCTTTCCA & 32 & Antisense \\
\hline $11.0102,1201,1401$ & TGTCTGCAATAGGTGTC & 81 & Antisense \\
\hline 12. $1501,1502, \mathrm{DRB} 55^{\star} 0201,0202$ & CGGCCCGCGCCTGCTCC & 74 & Antisense \\
\hline 13. 0301,0302 & TGCAGTAGTTGTCCACC & 80 & Antisense \\
\hline 14. 0401,0409 & CACCGCGGCCCGCTTCTGCTC & 75 & Antisense \\
\hline 15. $0103,0402,1301-2,1102-3$ & CCCGCTCGTCTTCCAGG & 73 & Antisense \\
\hline 16. $0101,0102,0403-08,1402$ & CGGCCCGCCTCTGCTCC & 74 & Antisense \\
\hline 17. $1101,1102,1103,1104$ & AGTCTCCTCATCAGGC & 41 & Antisense \\
\hline 18. $0302,1402, \mathrm{DRB} 3{ }^{\star} 0301$ & GAAGTATCTCTCCAGGA & 31 & Antisense \\
\hline 19. $0301,0302,1301,1302,1402$ & CGCACGTTCTCCTCCTGGTTA & 39 & Antisense \\
\hline
\end{tabular}

adding 1:1 (vol/vol) phenol/chloroform to one volume of ESP extract. The mixture was centrifuged and DNA precipitated from the aqueous phase. Further purification of the genomic DNA was carried out using the Wizard DNA Clean-up System (Promega).

Genotyping was done using polymerase chain reaction (PCR), followed by sequence specific oligonucleotide (SSO) analysis ${ }^{5}$ (fig 1).

The PCR amplification of the genomic DNA was carried out using the following forward and reverse primers: 5'-TGTCATTTCTT CAATGGGACG and 5'-TCGCCGCTG CACTGTGAAG, respectively. The thermocycling parameters used for the amplification of genomic DNA were: denaturation for 30 seconds at $93^{\circ} \mathrm{C}$, annealing for one minute at $55^{\circ} \mathrm{C}$, and extension for two minutes at $72^{\circ} \mathrm{C}$.

Approximately $0.5 \mu \mathrm{g}$ of the PCR amplification product was subjected to electrophoresis in agarose gel $(2 \%)$ and treated with denaturing solution followed by neutralising solution for one hour at room temperature. The blotting was performed overnight, DNA transferred to nylon filters (Hybond $\mathrm{N}$ ) and probed with ${ }^{32} \mathrm{P}$ labelled oligonucleotide probes (table 1). The probes were labelled using $\left[\gamma^{32} \mathrm{P}\right]$ ATP (60 $\mu \mathrm{Ci}$ ), $10 \mathrm{pmol}$ of oligonucleotide, and T4 polynucleotide kinase (NBL).

Following hybridisation, the membranes were washed twice at room temperature in $2 \times$ SSC (sodium chloride/sodium citrate) / 0.1\% SDS, and then in $100 \mathrm{ml}$ of tetramethyl ammonium chloride (TMAC) solution for 10 minutes; thereafter a final wash in TMAC was carried out at $56^{\circ} \mathrm{C}$. For reprobing, the filters were strip washed by immersing the filter in 0.4 $\mathrm{M} \mathrm{NaoH}$ at $42^{\circ} \mathrm{C}$ for 20 minutes followed by agitation in $0.2 \mathrm{M} \mathrm{HCl}(\mathrm{pH} 8.0), 0.1 \times \mathrm{SSPE}$ $\left(\mathrm{NaCl} / \mathrm{NaH}_{2} \mathrm{PO}_{4} / \mathrm{EDTA}\right) / 0.1 \%$ SDS for 20 minutes. The detection procedure was that recommended by The International Histocompatibility Workshop (Kimura and Suzuki, 1992). ${ }^{6}$ The oligonucleotide primers for PCR, SSO analysis were purchased from BSHI (the British Society for Histocompatibility and Immunogenetics, Bristol, UK).

\section{Results}

Two main DRB1 alleles observed in the patients were ${ }^{\star} 080$ and ${ }^{\star} 070$. Five of eight
Table 2 The frequency of HLA DRB1 alleles in the patients compared with normal white individuals

\begin{tabular}{lll}
\hline \multirow{3}{*}{ HLA DRB1 alleles } & \multicolumn{2}{l}{ Allele frequency in } \\
\cline { 2 - 3 } & Patients & Controls $\dagger$ \\
\hline$\star_{080}$ & 0.375 & 0.020 \\
$\star_{0} 70$ & 0.313 & 0.133 \\
$\star_{120}$ & 0.125 & 0.014 \\
$\star_{0} 010$ & 0.125 & 0.028 \\
& 0.062 & 0.133 \\
\hline
\end{tabular}

†The values for the distribution of HLA DRB1 alleles are compared with data given in references 4 and 5 .

patients with giant cell tumours of bone were found to be positive for DRB $1^{\star} 0801 / 3$ allele and four patients were positive for $\mathrm{DRB} 1^{\star} 070$. In the patients, the gene frequency of ${ }^{\star} 0801 / 3$ was 0.380 , which is 20 -fold higher than the reported genotype frequency in British whites. ${ }^{45}$ Other DRB1 alleles observed in the patients were ${ }^{\star} 120,{ }^{\star} 140$, and ${ }^{\star} 010$. The frequency of DRB1 alleles in the patients is compared with that in the normal population in table 2 .

\section{Discussion}

Although our study was performed on a comparatively small sample size, it shows a strong association with HLA-DRB ${ }^{\star} 080$ alleles. All but one patient with HLA-DRB $1^{\star} 080$ was found to have ${ }^{\star} 070$, suggesting that the 070/080 genotype may be associated with a particularly strong predisposition to HLA-DR negative giant cell tumour of bone. The other genotype observed in two patients was 120/ 140. The frequencies of $\star 120$ and ${ }^{\star} 140$ in the control population are known to be 0.014 and 0.028 , respectively, while in the patients studied the frequency of these alleles was found to be 0.125 (table 2).

These data support a clear association between HLA-DRB $1^{\star} 080$ and the formation of giant cell tumours of bone. The predominant haplotypes observed in our patients are those that have been identified in autoimmune disease but were not present in healthy controls. ${ }^{5}$ This observation raises a number of issues relating to the classification as well as the aetiology of giant cell tumour of bone. For instance, whether possessing the ${ }^{\star} 080$ allele increases the risk of giant cell tumour 
formation in bone, or of multinucleate giant cell tumours in other tissues, needs to be established in a larger study. Further studies are needed to determine whether the observed association between giant cell tumour of bone and DRB1 is likely to occur in other giant cell lesions of bone and soft tissues.

The demonstration of a predominance of a particular HLA type II antigen in individuals at risk of developing giant cell tumour of bone is of interest in view of the recent developments in the area of osteoclast-like multinucleate cell formation. These recent studies have shown that the cytokines TRANCE/RANKL (tumour necrosis factor (TNF) related, activation induced cytokine), which is produced by osteoblasts and T lymphocytes, and M-CSF, which is produced by macrophages and other inflammatory cells, are essential for osteoclastogenesis. $^{7-9}$ The mononuclear stromal cell component of giant cell tumour of bone is shown to contain largely osteoblast-like cells and macrophages. ${ }^{10}$ The signalling involved in stimulating the production of these cytokines from the stromal cells is not yet known, but the role of antigen presenting cells such as macrophages (APC cells) in this process is apparent from various previous studies demonstrating that the fusion of these cells requires monocyte/macrophage-bone stromal cell interaction. ${ }^{11-13}$ Therefore surface molecules, such as HLA class II antigen, may be crucial in affecting the release of cytokines and the formation of osteoclasts and osteoclast-like giant cells in giant cell tumour of bone.
HKD thanks The Wishbone Trust for their support.

1 McGrath. Giant-cell tumour of bone: an analysis of fifty-two cases. F Bone foint Surg Br 1972;54:216-29.

2 Doussis IA, Puddle B, Athanasou NA. Immunophenotype of multinucleated and mononuclear cells in giant cell lesions of bone and soft tissue. F Clin Pathol 1992;45:398404.

3 Rathod H, Malcolm AJ, Gillespie JI, et al. Characterization of a subtype of primary osteoclastoma: extracellular calcium but not calcitonin inhibits aggressive HLA-DRpositive osteoclastoma possessing 'functional' calcitonin positive osteoclastoma possessing
receptors. F Pathol 1994;174:293-9.

4 Doherty DG, Vaughan RW, Donaldson PT, et al. HLA DQA, DQB, and DRB genotyping by oligonucleotide analysis: distribution of alleles and haplotypes in British Caucasoids. Hum Immunol 1992;34:53-63.

5 Vaughan RW. PCR-SSO typing for HLA-DRB alleles. Eur $\mathcal{F}$ Immunogenet 1991;18:69-74.

6 Kimura A, Suzuki T. Reference protocol for the HLA/DNA typing technique. In: Dsuji SK, Aizawa M, Sasazuki T, eds. 11 th International Histocompatibility Workshop, vol 1. Oxford: Oxford University Press, 1991:397-419.

7 Yasuda H, Shima N, Nakagawa N, et al. Osteoclast differentiation factor is a ligand for osteoprotogerin/ tiation factor is a ligand for osteoprotogerin
osteoclastogenesis-inhibitory factor and is identical to osteoclastogenesis-inhibitory factor and is identical to
TRANCE/RANKL. Proc Natl Acad Sci USA 1998; 95:3597-602.

8 Rifas L, Holliday LS, Gluck SL, et al. Activated T cells induce osteoclastogenesis. Bone 1998 (programme and abstracts);23:S195.

9 Manabe N, Chikuda H, Nakamura, et al. Suppression of B-lymphopoiesis in the Klotho mouse exhibiting low turnover osteoporosis. Bone 1998 (programme and abstracts);23: s234

10 Joyner CJ, Quinn J, Triffitt JT, et al. Phenotypic characterisation of mononuclear and mutinucleated cells of giant cell tumour of bone. Bone Miner 1992;16:37-49.

11 Suda T, Takahasi N, Martin TJ. Modulation of osteoclast differentiation. Endocr Rev 1992;13:66-80.

12 Fujikawa Y, Quinn J, Sabokar A, et al. The human mononuclear osteoclast precursor circulates in the monocyte fraction. Endocrinology 1996;139:4058-60.

13 Fujikawa Y, Sabokbar A, Neale S, et al. Human osteoclast formation and bone resorption by monocytes and synovial macrophages in rheumatoid arthritis. Ann Rheum Dis 1996;55:1-7. 